\title{
Stability of maxillary anterior crowding treatment
}

Camila Leite Quaglio', Karina Maria Salvatore de Freitas², Marcos Roberto de Freitas ${ }^{3}$, Guilherme Janson ${ }^{4}$, José Fernando Castanha Henriques ${ }^{5}$

Objective: To evaluate the stability and the relapse of maxillary anterior crowding treatment on cases with premolar extraction and evaluate the tendency of the teeth to return to their pretreatment position.

Methods: The experimental sample consisted of 70 patients of both sex with an initial Class I and Class II maloclusion and treated with first premolar extractions. The initial mean age was 13,08 years. Dental casts' measurements were obtained at three stages (pretreatment, posttreatment and posttreatment of 9 years on average) and the variables assessed were Little Irregularity Index, maxillary arch length and intercanine. Pearson correlation coefficient was used to know if some studied variable would have influence on the crowding in the three stages (LII1, LII2, LII3) and in each linear displacement of the Little irregularity index (A, B, C, D, E) in the initial and post-retention phases.

Results: The maxillary crowding relapse ( LII3-2) is influenced by the initial (LIII), and the teeth tend to return to their pretreatment position.

Conclusion: The results underline the attention that the orthodontist should be given to the maxillary anterior relapse, primarily on those teeth that are crowded before the treatment.

Keywords: Crowding. Angle Class I malocclusion. Angle Class II malocclusion. Corrective Orthodontics.

${ }^{1}$ Msc in Orthodontics, School of Dentistry, University of São Paulo, Bauru. (FOB-USP).

${ }^{2}$ Head of Masters Course in Orthodontics, UNINGÁ, Professor of Orthodontics, Centro Universitário do Norte Paulista (UNORP, São José do Rio Preto).

${ }^{3}$ Head Professor of Orthodontics and Head of the PhD Course in Orthodontics, FOB-USP.

${ }^{4}$ Head Professor of Orthodontics and Head of the Masters Course in Orthodontics, FOB-USP.

${ }^{5}$ Head Professor of Orthodontics, Head of the Undergraduate Course in Orthodontics, FOB-USP.
How to cite this article: Quaglio CL, Freitas KMS, Freitas MR, Janson G, Henriques JFC. Stability of maxillary anterior crowding treatment. Dental Press J Orthod. 2012 July-Aug;17(4):57-64.

Submitted: April 27, 2009 - Revised and accepted: August 19, 2009

» The authors report no commercial, proprietary or financial interest in the products or companies described in this article.

Contact address: Camila Leite Quaglio

E-mail: clq@ajato.com.br 


\section{Estabilidade do tratamento de apinhamento anterossuperior}

Camila Leite Quaglio', Karina Maria Salvatore de Freitas², Marcos Roberto de Freitas ${ }^{3}$, Guilherme Janson ${ }^{4}$, José Fernando Castanha Henriques ${ }^{5}$

Objetivo: avaliar a estabilidade e recidiva do tratamento de apinhamento dos dentes anterossuperiores em casos com extrações de pré-molares e avaliar a tendência dos dentes apinhados, no início do tratamento, a retornar à sua posição original.

Métodos: a amostra consistiu de 70 pacientes de ambos os sexos, com má oclusão inicial de Classe I e Classe II de Angle, tratados com extrações dos primeiros pré-molares. A idade média inicial foi de 13,08 anos. Foram avaliados os modelos de estudo nas fases inicial $\left(\mathrm{T}_{1}\right)$, final $\left(\mathrm{T}_{2}\right)$ e, em média, 9 anos pós-tratamento $\left(\mathrm{T}_{3}\right)$ de cada paciente. As variáveis da arcada superior avaliadas e comparadas estatisticamente pela Análise de Variância (ANOVA) foram: índice de irregularidade de Little Superior (IRLS), comprimento da arcada (CAS) e distância intercaninos (DICS). O Teste de Correlação de Pearson foi utilizado para verificar se alguma variável estudada teria influência sobre o apinhamento nas três fases (IRLS $, I R L S_{2}, I R L S_{3}$ ) e em cada deslocamento de Little (A, B, C, D, E), na fase inicial e pós-tratamento.

Resultados: a recidiva do apinhamento superior $\left(\operatorname{IRLS}_{3-2}\right)$ é influenciada pelo apinhamento inicial (IRLS $)$, e os dentes tendem a voltar à posição original.

Conclusão: os resultados ressaltam a atenção que o ortodontista deve dar à recidiva anterossuperior, principalmente àqueles dentes que estavam apinhados antes do tratamento.

Palavras-chave: Recidiva. Má oclusão de Angle Classe I. Má oclusão de Angle Classe II. Ortodontia Corretiva.

\footnotetext{
${ }^{1}$ Mestre em Ortodontia, FOB-USP.

${ }^{2}$ Coordenadora do Mestrado Profissionalizante em Odontologia, área de concentração Ortodontia, UNINGÁ. Professora do curso de Especialização em Ortodontia, UNORP.

${ }^{3}$ Professor Titular da disciplina de Ortodontia e Coordenador do curso de PósGraduação em Ortodontia em nível de Doutorado, FOB-USP.

${ }^{4}$ Professor Titular da disciplina de Ortodontia e Coordenador do curso de PósGraduação em Ortodontia em nível de Mestrado, FOB-USP.

${ }^{5}$ Professor Titular da disciplina de Ortodontia, Coordenador do curso de Graduação e Professor do curso de Pós-Graduação em Ortodontia, FOB-USP.
}

Como citar este artigo: Quaglio CL, Freitas KMS, Freitas MR, Janson G, Henriques JFC. Stability of maxillary anterior crowding treatment. Dental Press J Orthod. 2012 July-Aug;17(4):57-64.

Enviado em: 27 de abril de 2009 - Revisado e aceito: 16 de agosto de 2009

» Os autores declaram não ter interesses associativos, comerciais, de propriedade ou financeiros, que representem conflito de interesse nos produtos e companhias descritos nesse artigo.

Endereço para correspondência: Camila Leite Quaglio E-mail: clq@ajato.com.br 


\section{INTRODUCTION}

In the last decades many patients have been seeking orthodontic treatment for esthetics reasons. Orthodontic treatment can improve facial esthetics as well as the occlusion, but long-term stability of the aligned teeth is highly variable and unpredictable. A wide variability of long-term results may be related to the amount of pretreatment crowding, treatment plan, patient's age and cooperation during and after treatment. ${ }^{22}$

For years, many papers on alignment stability researched mandibular anterior crowding, probably because relapse of these teeth are greater than that of the maxillary anterior teeth. ${ }^{4}$ More recently, patient's expectation have been considered, ${ }^{2,9,31}$ and for the patient, the alignment of the maxillary anterior teeth is especially important, since those teeth are the first to be shown on a smile. ${ }^{10,22}$ Since there is greater concern on the esthetics, a small relapse could be a problem. This new scenario obligates the orthodontists to seek out knowledge in order to inform their patients about this problem and to control the risk factors during and after orthodontic treatment.

Most studies have shown that crowding relapse appears to be multifactorial. ${ }^{10,15}$ The amount of initial crowding, the arch length, intercanine distance are the most studied factors. There is a consensus about the teeth's tendency to return toward their original position, ${ }^{1,5,12,14,22}$ but these studies are, in general, based on arches changes during the orthodontic treatment.

Therefore, in order to seek out for more knowledge on long term stability of maxillary anterior teeth on the orthodontic treatment, this paper evaluates the relapse of the maxillary anterior teeth in cases treated with premolar extractions and their tendency to return toward their original position.

\section{MATERIAL AND METHODS}

The sample was selected from the patient records treated in the Department of Orthodontics at Bauru Dental School, University of São Paulo and in the ACOPEN (Assessoria e Consultoria em Ortodontia, Pesquisa e Ensino). To minimize the bias, the sample was selected by inclusion criteria based on the literature ${ }^{4,10,12,17,19,25,29,30}$ and on the objective of this study. The selection criteria were patients with all permanent teeth erupted up to the first molars and under 15 years of age at pretreatment $\left(\mathrm{T}_{1}\right)$; no supernumerary teeth or tooth agenesis; no fiberotomy or interproximal stripping as part of the treatment plan; Class I or Class II Division 1 malocclusion of, at least, three-forths of a full step Class II molar relationship, no anterior open bite or crossbite and more than $3 \mathrm{~mm}$ of crowding on Little's irregularity index ${ }^{9}$ in the mandible (LIIMx). The pretreatment $\left(\mathrm{T}_{1}\right)$, posttreatment $\left(\mathrm{T}_{2}\right)$ and post-retention $\left(\mathrm{T}_{3}\right)$ dental casts had to be in good condition to be evaluated. All patients were treated with fixed edgewise appliances and they not underwent rapid maxillary expansion. The patients also had a maximum peer assessment rating (PAR) score of 5 and passive lip seal at posttreatment $\left(\mathrm{T}_{2}\right)$. Retention included a maxillary Hawley plate, used it 24 hours per day, for 6 months minimal plus 3 months during sleeping, and a bonded lingual canine-to-canine retainer in the mandibular arch. The post-retention dental casts $\left(\mathrm{T}_{3}\right)$ had to be at least 5 years after treatment. The presence of third molars was not part of the inclusion criteria because there is no common sense that have shown these teeth really interfere in anterior crowding relapse..$^{3,13,20,28}$

Therefore, the sample comprised 70 patients, 210 pairs of dental casts (pretreatment, posttreatment and post-retention).

\section{Variable collection method}

All dental cast measurements were made with a $0.01 \mathrm{~mm}$ precision digital caliper and capacity of $150 \mathrm{~mm}$ (Mitutoyo America, Aurora, Ill) by the same examiner. The examiner was blinded in relation to which group did the cast belong to in order to minimize the bias.

\section{The assessed variables: \\ Little's irregularity index (LII)}

The index used to evaluate the mandibular anterior crowding was proposed by Little ${ }^{18}$ and named after him. The Little's irregularity index was used because of its great reproductive, precision and it is used in the most studied about crowding and relapse. The variables described by this irregularity index 
were adapted to be evaluated on the maxillary arch. This adaptation was used in previous studies. ${ }^{6,10,21}$

In order to measure the amount of crowding a digital caliper was positioned parallel to the occlusal plane. Each linear displacement between the 5 anatomic contact points (A, B, C, D, E) of the anterior teeth were measure (Fig 1). Little's irregularity index comprises the 5 linear displacements added up, which represents the amount of crowding in the anterior teeth.

\section{Arch length (AL)}

It is the total distance, in millimeters, from the contact point of the maxillary central incisors to the mesial of the first permanent molars in the right (F) and left side (G) (Fig 2).

\section{Intercanine Width (ICW)}

Distance from the cusp tip of the upper canines in millimeters. In cases of cusp wear, the tip was estimated (Fig 2).

\section{Statistical method}

All statistical analyses were performed with Statistica software (version 6.0, Statsoft, Tulsa, Oklahoma). Normal distribution was verified by the KolmogorovSmirnov test and the results were considered significant

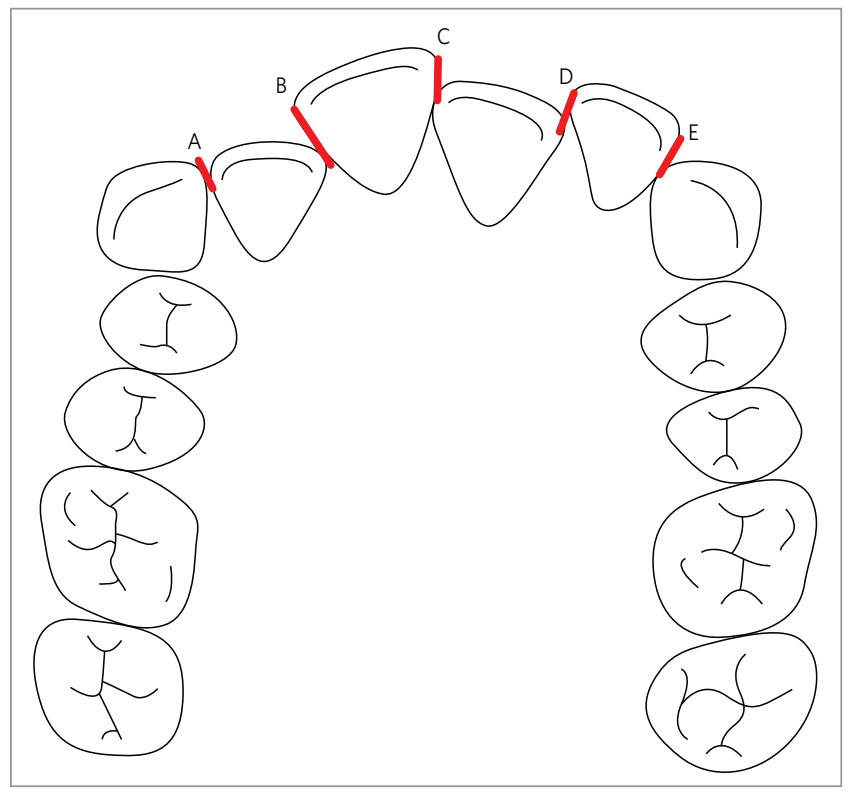

Figure 1 - Little's Irregularity Index for the Upper Arch: Sum of the distances $A+B+C+D+E$. when $\mathrm{p}<0.05$. The descriptive analysis found the mean, minimum, maximum, standard deviation, the groups and subgroups in all variables studied in the pretreatment $\left(\mathrm{T}_{1}\right)$; posttreatment $\left(\mathrm{T}_{2}\right)$, post-retention $\left(\mathrm{T}_{3}\right)$ casts, as well as, the difference between the posttreatment and pretreatment phase $\left(\mathrm{T}_{2}-\mathrm{T}_{1}\right)$ and the post-retention and posttreatment phase $\left(\mathrm{T}_{3}-\mathrm{T}_{2}\right)$. The difference between $\mathrm{T}_{2}$ and $\mathrm{T}_{1}$ is considered to be treatment changes and the difference between $\mathrm{T}_{3}$ and $\mathrm{T}_{2}$ is posttreatment changes.

\section{Method error}

The reliability of this study was evaluated by repeated measures of the variables of 15 patients (all phases) randomly chosen. The examiner had a month of interval between the first and the second measurement.

The systematic and casual error were evaluated for each variable. Systematic errors were evaluated with paired $t$ tests at $\mathrm{p}<0.05$, according to Houston. ${ }^{16}$ Casual errors were calculated according to Dahlberg's formula $\left(\mathrm{Se}^{2}=\mathrm{Sd}^{2} / 2 \mathrm{n}\right){ }^{7}$

\section{Statistical analyses}

Many studies in the literature are composed with Class I and Class II malocclusions in the same group. In this study, before the Class I and Class II malocclusion joined the same group the compatibility of

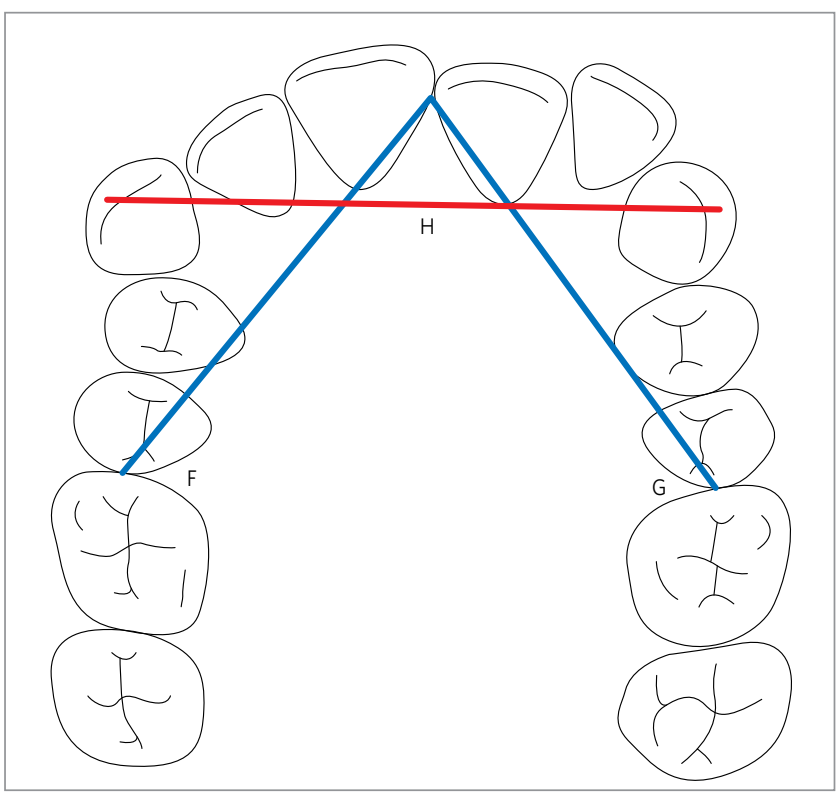

Figure 2 - $\mathrm{F}+\mathrm{G}$ - arch length; $\mathrm{H}$ - intercanine distance. 
these two malocclusions was evaluated. The sample was divided into 3 groups: Group 1 (Class I malocclusion treated with 4 first premolar extraction), group 2 (Class II division 1 malocclusion treated with 4 first premolar extraction), group 3 (Class II division 1 malocclusion treated with 2 first maxillary premolar extraction). Intergroup comparisons of all variables were made by one-way analysis of variance (ANOVA). Intergroup sex distribution was evaluated with the chi-square test.

Pearson correlation coefficients were used to assess the relationships between the variables (LIIMx, AL, ICW, posttreatment time and post-retention time). Another evaluation, was the correlation between each linear displacement of Little's irregularity index (A, B, C, D, E). In that way, it was possible to verify the tendency of the teeth to return toward their original position (A1A3, B1B3, ClC3, D1D3, E1D3). The relapse also was evaluated in each linear displacement from Little's irregularity index by using the scores in the pretreatment $\left(\mathrm{T}_{1}\right)$ and post-retention $\left(\mathrm{T}_{3}\right)$ phases. Any contact point that was correctly adjusted $(0 \mathrm{~mm})$, in any one of these phases $\left(\mathrm{T}_{1}\right.$ or $\left.\mathrm{T}_{3}\right)$, was not considered. All other linear displacements were used. The percentages of teeth that kept the same labiolingual direction at $\mathrm{T}_{1}$ and $\mathrm{T}_{3}$ were calculated.

The last comparison regarded the severity of the pretreatment crowding. The whole sample was divided in 2 groups (A and B). Group A comprised patients with LIIMx scores less than $7 \mathrm{~mm}$, or minimal and moderate irregularity (19 patients), while group B had LIIMx scores equal to or greater than $7 \mathrm{~mm}$, or severe and very severe irregularity (51 patients). The ratio between the post-retention changes (LIIMx3-2) and the correction amounts (LIIMx2-1) was called the relapse percentage. The absolute score of the correction amounts was used. The posttreatment changes that had negative scores (a greater alignment of the contact point) was considered to be zero.

\section{RESULTS}

\section{Method error}

Variables showed casual error smaller than $1 \mathrm{~mm}$. Among all 30 variables, only width $\mathrm{D}$ at $\mathrm{T}_{2}$ showed a significant systematic error (96\% precision).

\section{Statistical analises}

The table 1 and 2 show the compatibility between the 3 groups regarding variables (Tab l) and gender (Tab 2).

The table 3 shows the mean, minimum, maximum, standard deviation and total sample. Pearson correlation coefficients were used to assess the relationships of LIIMx scores at different stages with the other variables (Tab 4). There was a positive correlation between LIIMxl x LIIMx3, LIIMxl x LIIMx3-2 and LIIMx 2 x LIIMx3. There was a negative correlation between LIIMx2-1 x LIIMx3-2. Table 5 shows the correlation between the linear distance in the post-retention $\left(\mathrm{T}_{3}\right)$ and pretreatment $\left(\mathrm{T}_{1}\right)$ phase in $\mathrm{B}, \mathrm{C}$ and $\mathrm{D}$.

The sample consisted of 70 patients, each patient had 5 anatomic contact points described by Little $^{18}$ (Fig 1); totalling of 350 contact points. In the pretreatment phase, there were 309 linear displacements for labiolingual direction. The amount of linear displacement in post-retention phase was verified at the same contact points of the 309 linear displacements in pretreatment. The total of linear displacement in post-retention phase was 184 . These 184 linear displacements were used to evaluate the tendency that a tooth had to return toward its original position. A total of 142 anatomic contact points in the pretreatment phase had the same labiolingual direction in the post-retention phase. These results have shown that $77 \%$ of the labiolingual linear displacement had the tendency to return toward their original position.

The total sample was divided in group A (LIIMxl $<7 \mathrm{~mm}$ ) and group B (LIIMxl $>7 \mathrm{~mm}$ ) in order to evaluate the pretreatment severity crowding with the relapse percentage. The paired $t$ test did not show a significant difference among these variables (Tab 6).

\section{DISCUSSION}

Groups 1, 2, 3 were compatible regarding all variables (Tab 1 and 2), therefore the total sample (70 patients) could be evaluated. The maxillary anterior crowding relapse (LIIMx3-2) of the total sample was $1.07 \mathrm{~mm}$ (Tab 3). Since the percentage is the easiest way to visualize a result, there was an $11.88 \%$ of maxillary anterior crowding relapse. This percentage was the result from the posttreatment changes 
(LIIMx3-2) divided by the treatment changes (LIIMx2-1) multiplied by 100. Others studies in the orthodontic literature had similar results ${ }^{10,11,15,21,22}$. Our result showed a great stability of the maxillary anterior alignment, $88,12 \%$.

Pearson correlation test was used to assess the relationships of LIIMx scores at different stages with the other variables. There was a significant positive correlation between Little's irregularity index at pretreatment (LIIMxl) and the posttreatment changes (LIIMx3-2). This result shows that pretreatment maxillary anterior crowding is correlated with the posttreatment maxillary anterior crowding (Tab 4), and this is supported by previous studies that have shown that pretreatment maxillary anterior crowding interfere in the crowding relapse., ${ }^{1,824}$

The posttreatment Little's irregularity index (LIIMx2) has a significant positive correlation with the post-retention Little's irregularity index (LIIMx3). The posttreatment changes (LIIMx3-2) did not show a significant correlation with the amount of posttreatment crowding (LIIMx2) (Tab 4). Both results must be analyzed together because the crowding relapse would be influenced by quality of treatment results (LIIMx2) only if there was a significant correlation between the amounts of posttreatment crowding (LIIMx2) and the posttreatment changes. Many previous studies, even

Table 1 - Intergroup comparisons (1-way ANOVA).

\begin{tabular}{|c|c|c|c|c|c|c|c|}
\hline \multirow[t]{2}{*}{ Variable } & \multicolumn{2}{|c|}{$\begin{array}{c}\text { Group1 } \\
\text { Class I, } \\
4 \text { extractions }\end{array}$} & \multicolumn{2}{|c|}{$\begin{array}{c}\text { Group } 2 \\
\text { Class II division 1, } \\
4 \text { extractions }\end{array}$} & \multicolumn{2}{|c|}{$\begin{array}{c}\text { Group } 2 \\
\text { Class II division 1, } \\
2 \text { extractions }\end{array}$} & \multirow[t]{2}{*}{$\mathbf{p}$} \\
\hline & Mean & S.D. & Mean & S.D. & Mean & S.D. & \\
\hline Pretreatment $\left(T_{1}\right)$ age $(y)$ & $13.16^{\mathrm{A}}$ & 0.97 & $12.95^{\mathrm{A}}$ & 1.08 & $13.09^{A}$ & 1.11 & 0.760 \\
\hline Posttreatment $\left(\mathrm{T}_{2}\right)$ age $(\mathrm{y})$ & $15.15^{\mathrm{A}}$ & 1.14 & $15.43^{A}$ & 1.28 & $15.14^{\mathrm{A}}$ & 1.10 & 0.604 \\
\hline Post-retention $\left(\mathrm{T}_{3}\right)$ age $(\mathrm{y})$ & $23.71^{\mathrm{A}}$ & 2.80 & $24.97^{A}$ & 4.02 & $25.02^{\mathrm{A}}$ & 2.85 & 0.159 \\
\hline Posttreatment assessment & $8.55^{\mathrm{A}}$ & 3.03 & $9.54^{\mathrm{A}}$ & 4.27 & $9.88^{\mathrm{A}}$ & 2.87 & 0.209 \\
\hline Post-retention assessment & $7.31^{\mathrm{A}}$ & 3.18 & $8.26^{A}$ & 4.47 & $8.78^{A}$ & 2.95 & 0.191 \\
\hline $\mathrm{LII}_{1}$ & $8.59^{A}$ & 3.08 & $11.10^{A}$ & 4.46 & $9.68^{A}$ & 4.00 & 0.077 \\
\hline $\mathrm{CAS}_{1}$ & $71.04^{\mathrm{A}}$ & 3.79 & $70.48^{A}$ & 4.38 & $69.88^{A}$ & 3.63 & 0.590 \\
\hline $\mathrm{DICS}_{1}$ & $34.78^{A}$ & 2.25 & $34.56^{\mathrm{A}}$ & 2.81 & $34.49^{A}$ & 2.90 & 0.917 \\
\hline $\mathrm{LII}_{2}$ & $0.80^{A}$ & 0.90 & $0.61^{\mathrm{A}}$ & 0.52 & $0.64^{\mathrm{A}}$ & 0.55 & 0.601 \\
\hline $\mathrm{CAS}_{2}$ & $62.05^{A}$ & 2.20 & $62.91^{A}$ & 1.96 & $61.06^{A}$ & 2.98 & 0.096 \\
\hline $\mathrm{DICS}_{2}$ & $34.73^{\mathrm{A}}$ & 1.75 & $35.59^{A}$ & 2.00 & $34.72^{\mathrm{A}}$ & 1.55 & 0.194 \\
\hline $\mathrm{LII}_{3}$ & $1.79^{A}$ & 1.59 & $2.07^{A}$ & 1.44 & $1.43^{\mathrm{A}}$ & 1.03 & 0.361 \\
\hline $\mathrm{CAS}_{3}$ & $60.66^{A}$ & 2.26 & $61.40^{A}$ & 3.59 & $60.13^{A}$ & 3.01 & 0.381 \\
\hline $\mathrm{DICS}_{3}$ & $34.58^{A}$ & 1.58 & $35.03^{A}$ & 1.97 & $34.87^{A}$ & 2.22 & 0.689 \\
\hline $\mathrm{LII}_{3-2}$ & $0.97^{A}$ & 1.28 & $1.46^{\mathrm{A}}$ & 1.42 & $0.79^{A}$ & 1.05 & 0.223 \\
\hline $\mathrm{CAS}_{3-2}$ & $-1.39^{A}$ & 1.37 & $-1.50^{A}$ & 2.47 & $-0.93^{A}$ & 1.36 & 0.544 \\
\hline $\mathrm{DICS}_{3-2}$ & $-0.16^{A}$ & 1.02 & $-0.56^{A}$ & 1.15 & $0.15^{\mathrm{A}}$ & 1.30 & 0.155 \\
\hline
\end{tabular}

Table 2 - Intergroup comparison of gender distribution (chi-square test).

\begin{tabular}{ccccc} 
Gender & $\begin{array}{c}\text { Group 1 Class I, } \\
\text { 4 extractions }\end{array}$ & $\begin{array}{c}\text { Group 2 Class II division 1, } \\
\text { 4 extractions }\end{array}$ & $\begin{array}{c}\text { Group 2 Class II division 1, } \\
\text { 2 extractions }\end{array}$ \\
\hline Male & 12 & 11 & 11 & 34 \\
Female & 18 & 9 & 20 & 36 \\
Total & 30 & 20 & & 70 \\
& & chi-square $=1.544 \mathrm{df}=2 \mathrm{P}=0.462$ & \\
\hline
\end{tabular}


Table 3 - Descriptive analysis of the sample.

\begin{tabular}{|c|c|c|c|c|}
\hline \multirow{2}{*}{ Variable } & \multicolumn{4}{|c|}{ Sample $\mathbf{N}=\mathbf{7 0}$} \\
\hline & Mean & Minimun & Maximun & S.D \\
\hline LIIMx1 (mm) & 9.62 & 3.21 & 20.38 & 3.87 \\
\hline LIIM×2 (mm) & 0.70 & 0.00 & 3.44 & 0.71 \\
\hline LIIM×3 (mm) & 1.77 & 0.10 & 6.87 & 1.41 \\
\hline LIIMx2-1 (mm) & -8.92 & -19.48 & -2.94 & 3.77 \\
\hline LIIM×3-2 (mm) & 1.07 & -1.44 & 4.40 & 1.27 \\
\hline LIIM×3-1 (mm) & -7.85 & -18.57 & -1.85 & 3.61 \\
\hline Pretreatment $\left(T_{1}\right)$ age $(y)$ & 13.08 & 10.63 & 15.02 & 1.03 \\
\hline Pretreatment $\left(\mathrm{T}_{1}\right)$ age $(\mathrm{y})$ & 15.23 & 12.14 & 17.55 & 1.61 \\
\hline Pretreatment $\left(T_{1}\right)$ age $(y)$ & 24.44 & 18.84 & 33.11 & 3.22 \\
\hline $\begin{array}{l}\text { Post-retention } \\
\text { observation (y) }\end{array}$ & 9.21 & 5.00 & 17.23 & 3.39 \\
\hline
\end{tabular}

Table 4 - Pearson correlation test.

\begin{tabular}{|c|c|c|}
\hline Variable & $\mathbf{R}$ & $\mathbf{p}$ \\
\hline $\operatorname{LIIM\times 1\times }$ LIIMx2 (mm) & 0.2227 & 0.064 \\
\hline $\operatorname{LIIMx1} \times \operatorname{LIIMx3}(\mathrm{mm})$ & 0.3596 & $0.002^{\star}$ \\
\hline LIIMx1 x LIIM×3-2 (mm) & 0.2698 & $0.024^{\star}$ \\
\hline $\operatorname{LIIM} 2 \times \operatorname{LIIM} \times 3(\mathrm{~mm})$ & 0.4380 & $0.000^{*}$ \\
\hline LIIM×2-1 x LIIM×3-2 (mm) & -0.2921 & $0.014^{*}$ \\
\hline LIIM×3 x LIIM×3-2 (mm) & -0.0832 & 0.494 \\
\hline LIIMx3x AL3 (mm) & 0.0449 & 0.712 \\
\hline LIIMx3 x ICW3 (mm) & -0.0973 & 0.423 \\
\hline LIIM×3 x Posttreatment observation $(\mathrm{mm})$ & 0.1160 & 0.339 \\
\hline LIIM $3 \times 3$ Pretreatment age $(y)$ & 0.0929 & 0.444 \\
\hline LIIMx3 x Posttreatment age $(\mathrm{y})$ & -0.0035 & 0.977 \\
\hline LIIM×3 x Post-retention age $(\mathrm{y})$ & 0.1207 & 0.319 \\
\hline LIIM×3-2 x AL3-2 (mm) & 0.0557 & 0.647 \\
\hline LIIM×3-2 x ICW3-2 (mm) & -0.1371 & 0.258 \\
\hline
\end{tabular}

${ }^{*} p<0,05 \%$

Table 5 - Pearson correlation test between the variables A, B, C, D, E in the post-retention $\left(T_{3}\right)$ and pretreatment $\left(T_{1}\right)$ phases.

\begin{tabular}{ccc}
\hline Variable & $\mathbf{R}$ & $\mathbf{p}$ \\
$\mathrm{A} 3 \times \mathrm{A} 1(\mathrm{~mm})$ & 0.1504 & 0214 \\
$\mathrm{~B} 3 \times \mathrm{B} 1(\mathrm{~mm})$ & 0.4586 & $0.000^{\star}$ \\
$\mathrm{C} 3 \times \mathrm{C} 1(\mathrm{~mm})$ & 0.3592 & $0.002^{\star}$ \\
$\mathrm{D} 3 \times \mathrm{D} 1(\mathrm{~mm})$ & 0.4977 & $0.000^{\star}$ \\
$\mathrm{E} 3 \times \mathrm{E} 1(\mathrm{~mm})$ & 0.0386 & 0.751 \\
\hline
\end{tabular}

${ }^{*} p<0,05 \%$.

Table 6 - Paired $t$ test between the pretreatment severity crowding with the relapse percentage.

\begin{tabular}{cccccc} 
& Group A & \multicolumn{4}{c}{ Group B } \\
Variable & Severity & S.D. & Severity & S.D. & $\mathbf{p}$ \\
& $<\mathbf{~ m m}$ & & $>\mathbf{7} \mathbf{~ m m}$ & & \\
\hline Pretreatment age $(\mathrm{y})$ & 15.41 & 12.12 & 12.40 & 16.86 & 0.068 \\
\hline
\end{tabular}

though being about mandibular anterior crowding, corroborated with this study. ${ }^{22,23,24}$ The positive significant correlation between posttreatment Little's irregularity index (LIIMx2) and post-retention Little's irregularity index (LIIMx3) is that posttreatment crowding is, at least, the same after a long-term evaluation.

Changes during treatment (LIIMx2-1) had a significant correlation with the post-retention changes (LIIM x 3-2) (Tab 4). Despite this negative correlation, it is considered to be a false negative. Since LIIMx2-1 has a negative sign (posttreatment crowding minus pretreatment crowding) and the variable LIIMx3-2 has a positive sign (post-retention crowding minus pretreatment crowding); when these two variables are correlated, the negative sign is maintained as a positive correlation result.

The post-retention crowding (LIIMx3) was evaluated with the posttreatment arch length and intercanine width (AL3, ICW3), posttreatment observation and age in all phases. These variables were chosen because the literature presented some studies with significant positive correlation between the post-retention crowding (LIIMx3) and these variables $^{1,27,30}$ (Tab 4). None of these variables was significantly correlated.

The Pearson correlation coefficients were used to assess the relationships between linear displacements of the anatomic contact points at $\mathrm{T}_{1}$ and $\mathrm{T}_{3}$. The percentages of teeth that kept the same labiolingual direction at $\mathrm{T}_{1}$ and $\mathrm{T}_{3}$ were calculated. There were significant positive correlations among linear displacements of anatomic contact point B (mesial surface of maxillary right lateral incisor with distal surface of maxillary right central incisor), contact point $\mathrm{C}$ (mesial surface of maxillary right central incisor with distal surface of maxillary left central incisor), and contact point D (mesial surface of maxillary left lateral incisor with distal maxillary left central incisor) at $\mathrm{T}_{1}$ and $\mathrm{T}_{3}$ (Tab 5). These small proximal surfaces could cause a weak contact point which could increase susceptibility of misalignment over the years. The literature has not evaluated the recurrence of crowding the way our study has, in each region of the Little Index (A, B, C, D and E), so our study should not be compared directly with any study published. 
The literature has showned the teeth tendency to return to its original position by evaluating rotation or only by the assuming when there was a statistical correlation between total relapse and initial crowding. ${ }^{1,8,22,24,30}$ If the Little's irregularity index is evaluated carefully, it does not show the teeth tendency to return to their original position. The Little's irregularity index is the sum of 5 displacements (A, B, C, D, E) and it does not evaluate the direction of each anterior tooth in relation to its adjacent teeth (labial or lingual). To answer this question the models were evaluated again taking into consideration the labiolingual direction in the pretreatment phase $\left(\mathrm{T}_{1}\right)$ and in the post-retention phase $\left(\mathrm{T}_{3}\right)$. From the 309 regions that showed labiolingual displacement in pretreatment phase, 184 regions showed labiolingual displacement in post-retention phase. There were 142 regions in post-retention phase that had the same pattern of displacement. This means that around $77 \%$ of the regions had the same pattern of displacement over the years, showing that the teeth have a tendency to return to the original position.

The significant correlation has shown that the pretreatment crowding pattern has some influence in posttreatment crowding, but this correlation does not show if the pretreatment crowding pattern has influence in posttreatment crowding percentage, or in other words: "Does the teeth with greater pretreatment crowding tend to have more crowding relapse and vice-versa?" To answer this question the total sample was divided into two groups: Group A with moderate crowding (4-6 mm), and Group B with severe and very severe crowding (from $7 \mathrm{~mm}$ ). ${ }^{18}$ The comparison of the posttreatment crowding percentage between these two groups showed no significant difference (Tab 6). This result does not show an influence of the pretreatment crowding on the crowding relapse percentage, even though the mean of the crowding relapse percentage of the Group A (severity $>7 \mathrm{~mm}$ ) was greater that crowding relapse percentage of the Group B (severity $<7 \mathrm{~mm}$ ). A similar study with this comparison showed significant diferrences. ${ }^{12}$ That could be explained by the $8^{\text {th }}$ Riedel's theorem ${ }^{26}$ which states that the further teeth have been moved, they are less likely to relapse. Therefore, the relationship between the pretreatment crowding and the posttreatment crowding relapse might exist but this relationship should be carefully used when it comes to the pretreatment crowding severity and posttreatment relapse. It means that $2 \mathrm{~mm}$ of posttreatment crowding in a case with $4 \mathrm{~mm}$ of pretreatment crowding is $50 \%$ of relapse, but $4 \mathrm{~mm}$ of posttreatment crowding in a case with $12 \mathrm{~mm}$ of pretreatment crowding is $33 \%$ of relapse. The amount of relapse shows that the case with the greater amount of pretreatment crowding had a greater relapse, but the percentage was lower.

\section{Final considerations}

Nowadays the patient is concerned about having an esthetic smile so many orthodontic treatments are aimed in correcting crowding. The increased demand for orthodontic treatment is a positive fact to the orthodontists but they cannot forget that the teeth appears to have a posttreatment "agenda". Orthodontists have to be more careful in cases where the patients seek treatment only to align a tooth that bothers him. After treatment and over the years, the same tooth could be back to a similar position. To avoid any failure, the orthodontist must be stringent in correcting this irregularity and on the retention plan. The patient has to be aware of the treatment and the posttreatment risks.

\section{CONCLUSION}

» The stability of maxillary anterior alignment in the whole sample was $88.12 \%$, in an average of 9 years of posttreatment.

» There was a significant positive correlation between the amounts of pretreatment maxillary anterior crowding and the maxillary anterior relapse. The greater was the amount of pretreatment crowding, the greater was the relapse.

» The maxillary anterior teeth tend to return to their original positions. 


\section{REFERENCES}

1. Artun J, Garol JD, Little RM. Long-term stability of mandibular incisors following successful treatment of Class II, Division 1, malocclusions. Angle Orthod. 1996;66(3):229-38.

2. Bedi R, Gulati N, McGrath C. A study of satisfaction with dental services among adults in the United Kingdom. Br Dent J. 2005 Apr 9;198(7):433-7.

3. Bishara SE. Third molars: a dilemma! Or is it? Am J Orthod Dentofacial Orthop. 1999 Jun;115(6):628-33.

4. Bondemark L, Holm AK, Hansen K, Axelsson S, Mohlin B, Brattstrom V, et al. Long-term stability of orthodontic treatment and patient satisfaction. A systematic review. Angle Orthod. 2007 Jan;77(1):181-91.

5. Burke SP, Silveira AM, Goldsmith LJ, Yancey JM, Van Stewart A, Scarfe WC. A meta-analysis of mandibular intercanine width in treatment and post-retention. Angle Orthod. 1998 Feb;68(1):53-60

6. Canuto $\mathrm{L}$. Avaliação da influência da realização da expansão rápida da maxila sobre a recidiva do apinhamento ântero-superior, em casos tratados ortodonticamente sem extrações [Dissertação]. Bauru (SP): Universidade de São Paulo, Faculdade de Odontologia de Bauru; 2006.

7. Dahlberg G. Statistical methods for medical and biological students. New York: Interscience; 1940.

8. de la Cruz A, Sampson P, Little RM, Artun J, Shapiro PA. Long-term changes in arch form after orthodontic treatment and retention. Am J Orthod Dentofacial Orthop. 1995 May;107(5):518-30

9. de Oliveira CM, Sheiham A. Orthodontic treatment and its impact on oral healthrelated quality of life in Brazilian adolescents. J Orthod. 2004 Mar;31(1):20-7; discussion 15

10. Destang DL, Kerr WJ. Maxillary retention: is longer better? Eur J Orthod. 2003 Feb;25(1):65-9.

11. Erdinc $A E$, Nanda RS, Işiksal E. Relapse of anterior crowding in patients treated with extraction and nonextraction of premolars. Am J Orthod Dentofacial Orthop. 2006 Jun;129(6):775-84.

12. Freitas KM, de Freitas MR, Henriques JF, Pinzan A, Janson G. Post-retention relapse of mandibular anterior crowding in patients treated without mandibular premolar extraction. Am J Orthod Dentofacial Orthop. 2004 Apr;125(4):480-7.

13. Harradine NW, Pearson $\mathrm{MH}$, Toth $\mathrm{B}$. The effect of extraction of third molars on late lower incisor crowding: a randomized controlled trial. Br J Orthod. 1998 May;25(2):117-22.

14. Heiser W, Niederwanger A, Bancher B, Bittermann G, Neunteufel N, Kulmer S. Three-dimensional dental arch and palatal form changes after extraction and nonextraction treatment. Part 1. Arch length and area. Am J Orthod Dentofacial Orthop. 2004 Jul;126(1):71-81.

15. Heiser W, Richter M, Niederwanger A, Neunteufel N, Kulmer S. Association of the canine guidance angle with maxillary and mandibular intercanine widths and anterior alignment relapse: Extraction vs nonextraction treatment. Am J Orthod Dentofacial Orthop. 2008 May:133(5):669-80.
16. Houston WJ. The analysis of errors in orthodontic measurements. Am J Orthod. 1983 May;83(5):382-90.

17. Huang $\mathrm{L}$, Artun J. Is the post-retention relapse of maxillary and mandibular incisor alignment related? Am J Orthod Dentofacial Orthop. 2001 Jul;120(1):9-19.

18. Little RM. The irregularity index: a quantitative score of mandibular anterior alignment. Am J Orthod. 1975 Nov;68(5):554-63.

19. Little RM, Riedel RA, Engst ED. Serial extraction of first premolars-post-retention evaluation of stability and relapse. Angle Orthod. 1990 Winter;60(4):255-62.

20. Little RM, Riedel RA, Stein A. Mandibular arch length increase during the mixed dentition: post-retention evaluation of stability and relapse. Am J Orthod Dentofacial Orthop. 1990 May;97(5):393-404.

21. Martins P. Avaliação da influência da realização da expansão rápida da maxila sobre a recidiva do apinhamento ântero-superior, em casos tratados ortodonticamente com extrações de pré-molares [Dissertação]. Bauru (SP): Universidade de São Paulo, Faculdade de Odontologia; 2007.

22. Naraghi $\mathrm{S}$, Andrén A, Kjellberg $\mathrm{H}$, Mohlin BO. Relapse tendency after orthodontic correction of upper front teeth retained with a bonded retainer. Angle Orthod. 2006 Jul; 76(4):570-6.

23. Nett BC, Huang GJ. Long-term posttreatment changes measured by the American Board of Orthodontics objective grading system. Am J Orthod Dentofacial Orthop. 2005 Apr;127(4):444-50; quiz 516.

24. Ormiston JP, Huang GJ, Little RM, Decker JD, Seuk GD. Retrospective analysis of long-term stable and unstable orthodontic treatment outcomes. Am J Orthod Dentofacial Orthop. 2005 Nov:128(5):568-74; quiz 669.

25. Pepicelli A, Woods M, Briggs C. The mandibular muscles and their importance in orthodontics: a contemporary review. Am J Orthod Dentofacial Orthop. 2005 Dec;128(6):774-80

26. Riedel RA. A review of the retention problem. Angle Orthod. 1960 Oct;30:179-99.

27. Rothe LE, Bollen AM, Little RM, Herring SW, Chaison JB, Chen CS, Hollender LG. Trabecular and cortical bone as risk factors for orthodontic relapse. Am J Orthod Dentofacial Orthop. 2006 Oct;130(4):476-84.

28. Southard TE, Southard KA, Weeda LW. Mesial force from unerupted third molars. Am J Orthod Dentofacial Orthop. 1991 Mar;99(3):220-5

29. Taner TU, Haydar B, Kavuklu I, Korkmaz A. Short-term effects of fiberotomy on relapse of anterior crowding. Am J Orthod Dentofacial Orthop. 2000 Dec;118(6):617-23.

30. Vaden JL, Harris EF, Gardner RL Relapse revisited. Am J Orthod Dentofacial Orthop. 1997 May;111(5):543-53.

31. Zhang $M, M c G$ rath $C$, Hägg U. Patients expectations and experiences of fixed orthodontic appliance therapy. Impact on quality of life. Angle Orthod. 2007 Mar;77(2):318-22 